\title{
Pengaruh Model Pembelajaran Berbasis Masalah dan Group Investigation Terhadap Hasil Belajar dan Kemampuan Berpikir Kreatif Pada Materi Sistem Pencernaan Makanan di SMA Negeri 1 Muara Batu Kabupaten Aceh Utara
}

\author{
Elsa Bunga Dayanti ${ }^{1}$ Hasruddin ${ }^{2}$ Syahmi Edi ${ }^{2}$ \\ ${ }^{1}$ Alumni Program Studi Pendidikan Biologi Program Pascasarjana Universitas Negeri Medan, Sumatera Utara, \\ Indonesia \\ ${ }^{2}$ Program Studi Pendidikan Biologi, Program Pascasarjana, Universitas Negeri Medan \\ E-mail: bungaelsady@gmail.com
}

\begin{abstract}
This study was aimed to determine the effect of problem based learning and group investigation on: (1) learning outcomes; and (2) creative thinking ability of student in class XI of SMAN 1 Muara Batu. This type of research is a quasi-experimental research with pretest-posttest control group design. Samples were selected using random cluster sampling technique and divided into experimental and control classes. Class XI IPA 3 was applied problem-based learning model, class XI IPA ${ }_{1}$ was applied to the model group investigation, and class XI IPA ${ }_{2}$ was applied in the conventional learning (control). Multiple choices were used to measure learning outcomes, while tests of creative thinking skills in the form of essay questions. Data were analyzed using Analysis Covarian (Anacova) at significance level $\alpha=0.05$ and followed by Tukey's test with SPSS 21.0. The results showed that: (1) There was an effect of learning model to the learning outcomes of students $(\mathrm{F}=$ $14.183, \mathrm{P}=0.000$ ). Students who were taught by problem-based learning model was significantly different from those of group investigation and conventional learning model; and (2) There was an effect of learning model to students creative thinking abilities $(\mathrm{F}=12.030, \mathrm{P}=0.000)$. Students who were taught by problem-based learning model was not significantly different from the group investigation model but differed significantly with students who were taught by conventional learning model.
\end{abstract}

Key Word: Pembelajaran Berbasis Masalah, Group Investigation, Hasil Belajar, Kemampuan Berpikir Kreatif.

\section{PENDAHULUAN}

Lembaga pendidikan adalah salah satu harapan besar bagi negeri ini agar bisa bangkit dari keterpurukan kualitas pendidikan dalam semua aspek dan jenjang pendidikan. Kualitas pendidikan tersebut sangat diperlukan untuk mendukung terciptanya manusia yang cerdas dan terampil (Ristanto, 2010).

Pendidikan sains diarahkan untuk mencari tahu dan berbuat sehingga dapat membantu peserta didik untuk memperoleh pemahaman yang lebih mendalam dan hubungannya dengan alam sekitar (BSNP, 2006). Hal ini berarti pembelajaran sains bukan hanya sekedar teori saja, melainkan harus melakukan aktivitas, mengetahui dan memiliki keterampilan yang berkaitan dengan pembelajaran sehingga mampu membentuk keterampilan yang dapat diaplikasikan pada kehidupan nyata
Keterampilan berpikir kreatif merupakan kemampuan yang harus dimiliki siswa dalam belajar sains. Berpikir kreatif dapat mendorong siswa untuk menyebutkan banyak ide dan contoh-contoh serta solusi penyelesaian yang berhubungan dengan kehidupannya. Hal ini dikarenakan berpikir kreatif merupakan tahapan bereksplorasi dan elemen penting dalam memecahkan masalah (Runco, 2004).

Materi Biologi adalah materi yang menekankan pengalaman langsung karena berhubungan dengan lingkungan. Salah satu materi biologi yang dibahas yaitu mengenai sistem pencernaan makanan. Dalam kehidupan sehari-hari, banyak permasalahan yang berkaitan dengan sistem pencernaan makanan yang tidak disadari siswa, dikarenakan siswa tidak terbiasa belajar melalui permasalahanpermasalahan. 
Dari hasil observasi, ditemukan masih banyak siswa yang tidak paham mengenai makanan yang mereka makan. Siswa juga tidak tahu bahwa adanya zat-zat aditif yang ditambahkan pada makanan sehingga tidak baik apabila dikonsumsi terlalu banyak. Sebagian siswa juga masih memilih-milih jajanan sesuai dengan rasanya, yang belum tentu sehat. Dari segi pemahaman materi, masih ada siswa yang belum mampu mengurutkan jalannya makanan berdasarkan sistem pencernaan makanan, menyebutkan dengan baik enzim-enzim yang terdapat dalam sistem pencernaan makanan dan organ yang mensekresikan enzim tersebut, serta hanya mampu menyebutkan satu atau dua penyakit saja yang berkaitan dengan sistem pencernaan makanan.

Berdasarkan hasil observasi peneliti tersebut, diketahui bahwa pembelajaran yang dilaksanakan oleh guru di SMA Negeri 1 Muara Batu, masih dominan konvensional, artinya pembelajaran masih berpusat kepada guru. Pembelajaran konvensional ini berbentuk ceramah, diskusi, dan tanya jawab. Proses diskusi dan tanya jawab yang terjadi di kelas hanya bersifat teoritis saja dan tidak bersifat kontekstual. Disisi lain muncul permasalahan lemahnya kemampuan siswa dalam menggunakan cara berpikirnya untuk menjawab soal berbentuk analisis. Hal ini dikarenakan guru cenderung menyampaikan informasi dengan cara berceramah di kelas sedangkan siswa mendengarkan apa yang dijelaskan oleh guru dan meniru apa yang dicatat oleh gurunya sehingga pengetahuan yang dimiliki siswa terbatas dengan apa yang diberikan oleh guru. Siswa tidak diajak untuk berpikir secara kreatif dengan menuangkan ide-idenya sendiri berkaitan dengan sistem pencernaan.

Pembelajaran konvensional juga mengarahkan siswa untuk mengahafal sejumlah informasi yang diberikan sehingga siswa sulit menghubungkan konsep satu dengan konsep lainnya dan sulit memahami konsep. Kondisi tersebut berdampak pada rendahnya hasil belajar siswa yang terlihat dari nilai rata-rata ujian semester dalam kurun waktu tiga tahun terakhir.

Kurang bervariasinya model pembelajaran yang dilakukan oleh guru di kelas memposisikan guru sebagai pentransfer pengetahuan. Pembelajaran dalam bentuk transfer pengetahuan kurang mampu meningkatkan kemampuan berpikir siswa. Padahal kemampuan berpikir akan muncul apabila selama proses pembelajaran, guru membangun pola interaksi dan komunikasi yang lebih menekankan pada proses pembentukan pengetahuan secara aktif.

Guru sebagai salah satu faktor penunjang keberhasilan dalam proses belajar mengajar memegang peranan penting untuk menjadikan siswa terampil. Salah satunya guru dapat menggunakan model-model pembelajaran untuk materi yang diajarkannya.

Model pembelajaran berbasis masalah adalah pembelajaran yang diterjemahan dari kata Problem based learning (PBL). PBM merupakan salah satu model pembelajaran yang mengorientasikan masalah diawal pembelajaran. Masalah dijadikan kasus untuk memulai suatu topik pembelajaran. PBM merupakan model pembelajaran yang sangat baik dalam merubah paradigma pendidikan sains. PBM menjadikan siswa sebagai pusat pembelajaran sehingga siswa ikut terlibat dalam pembelajaran mereka sendiri (Allchin, 2013).

Hasil penelitian Gordon et al dalam Sungur (2006) menemukan bahwa PBM membantu siswa mengembangkan keterampilan interpersonal, berpikir kritis dan mencari informasi. Awang dan Ishak (2008) menyatakan bahwa pembelajaran berbasis masalah dapat meningkatkan kemampuan berpikir kreatif, karena siswa diajak untuk berpikir dan menyelesaikan masalah

Seperti halnnya Pembelajaran Berbasis Masalah, pembelajaran group investigation (GI) juga merupakan model pembelajaran yang sesuai dengan paradigma konstruktivis. Siswa mendapatkan kesempatan seluas-luasnya untuk terlibat langsung dan aktif dalam proses pembelajaran mulai dari perencanaan 
sampai cara mempelajari suatu topik. Group Investigation (GI) memberi kebebasan kepada pembelajar untuk berfikir secara analitis, kritis, kreatif, reflektif dan produktif (Isjoni, 2009).

Dengan kelebihan yang ada dalam PBM dan Group Investigation (GI) maka perlu diteliti penggunaan kedua model pembelajaran ini pada materi sistem pencernaan makanan dengan menggunakan permasalahan-permaslahan yang kontekstual dengan kehidupan siswa sebagai solusi agar siswa lebih aktif dalam proses belajar sehingga dapat melatih kemampuan berpikir kreatif yang diharapkan dapat bermanfaat dalam kehidupan sehari-hari.

\section{METODE PENELITIAN}

Penelitian ini dilaksanakan di SMA Negeri 1 Muara Batu, pada kelas XI Semester Genap Tahun Pembelajaran 2015/2016 yang beralamat di Jln. Pendidikan No.5 Krueng Mane, Kecamatan Muara Batu Kabupaten Aceh Utara. Waktu penelitian dimulai dari bulan Januari 2016 sampai dengan April 2016.

Populasi dalam penelitian ini adalah seluruh siswa kelas XI SMA Negeri 1 Muara Batu dengan tahun pelajaran 2015/2016 sebanyak tujuh (7) kelas dengan jumlah 178 siswa. Pengambilan sampel menggunakan teknik Cluster Random Sampling. Kelas XI IPA ${ }_{3}$ diperoleh sebagai kelas eksperimen yang dibelajarkan menggunakan model pembelajaran berbasis masalah (PBM) dan XI IPA 1 sebagai kelas yang dibelajarkan dengan model kooperatif tipe group investigation (GI) dan kelas XI $\mathrm{IPA}_{2}$ sebagai kelas kontrol yang dibelajarkan dengan model ceramah.

Jenis penelitian yang digunakan adalah penelitian eksperimen semu (quasi eksperiment). Desain penelitian yang digunakan adalah pretest-postes control group design. Pengumpulan data dilakukan dengan memberikan tes untuk mengukur hasil belajar siswa dan kemampuan berpikir kreatifnya. Tes dilakukan dua kali yaitu sebelum perlakuan (pretes) dan setelah perlakuan (postes). Instrumen yang digunakan untuk mengukur hasil belajar berupa soal pilihan berganda sebanyak 30 soal, yang disusun berdasarkan ranah taksomi Bloom $\left(\mathrm{C}_{1}-\mathrm{C}_{6}\right)$. Setiap jawaban benar diberi skor 1 dan jawaban salah diberi skor 0. Sedangkan tes berpikir kreatif diukur dengan menggunakan soal essay sebanyak 10 soal yang mencakup indikator berpikir lancar, luwes, orisinil, dan merinci.

Data hasil penelitian diolah dan dianalisis secar bertahap. Hipotesis diuji dengan menggunakan rumus Analisis Covarian (Anacova) pada taraf signifkansi $\alpha=0,05$. Ha (terdapat pengaruh) diterima apabila nilai signifikansi $<0,05$ dan sebaliknya. Apabila hasil uji statistik menunjukkan adanya pengaruh maka analisis dilanjutkan dengan uji Tukey. Pengolahan data dilakukan dengan menggunakan software SPSS 21.0

\section{HASIL DAN PEMBAHASAN Hasil}

Ringkasan data hasil penelitian disajikan dalam Tabel berikut ini:

Tabel 1.1 Deskripsi Hasil Belajar Siswa

\begin{tabular}{lcccc}
\hline \multirow{2}{*}{ Kelas } & \multicolumn{3}{c}{ Nilai Rata-rata } & \multicolumn{3}{c}{ Postes } \\
\cline { 2 - 5 } & \multirow{2}{*}{ Hasil Belajar } & Ket. Berpikir Kreatif & Hasil Belajar & Ket. Berpikir Kreatif \\
\hline PBM & 43,66 & 51,93 & 85,27 & 82,77 \\
GI & 43,68 & 51,44 & 80,80 & 80,07 \\
Konvensional & 43,67 & 51,26 & 76,78 & 77,00 \\
\hline
\end{tabular}

Pengaruh model pembelajaran terhadap hasil belajar siswa

Hasil analisis covarian (Anacova) dengan menunjukkan bahwa model pembelajaran yang diberikan berpengaruh terhadap hasil belajar siswa $(\mathrm{F}=14,183 ; \mathrm{P}$ $=0,000)$ Berdasarkan pengujian hipotesis maka Ha diterima dan Ho ditolak yang 
berarti terdapat pengaruh model dibandingkan dengan siswa yang pembelajaran terhadap hasil belajar.

Siswa yang dibelajarkan dengan model dibelajarkan dengan model group pembelajaran berbasis masalah (PBM) secara signifikan lebih tinggi $(85,26 \pm 6,81)$ investigation $(\mathrm{GI})(80,80 \pm 5,81)$ dan yang dibelajarkan secara konvensional yaitu $76,77 \pm 5,96$ (Gambar 1).

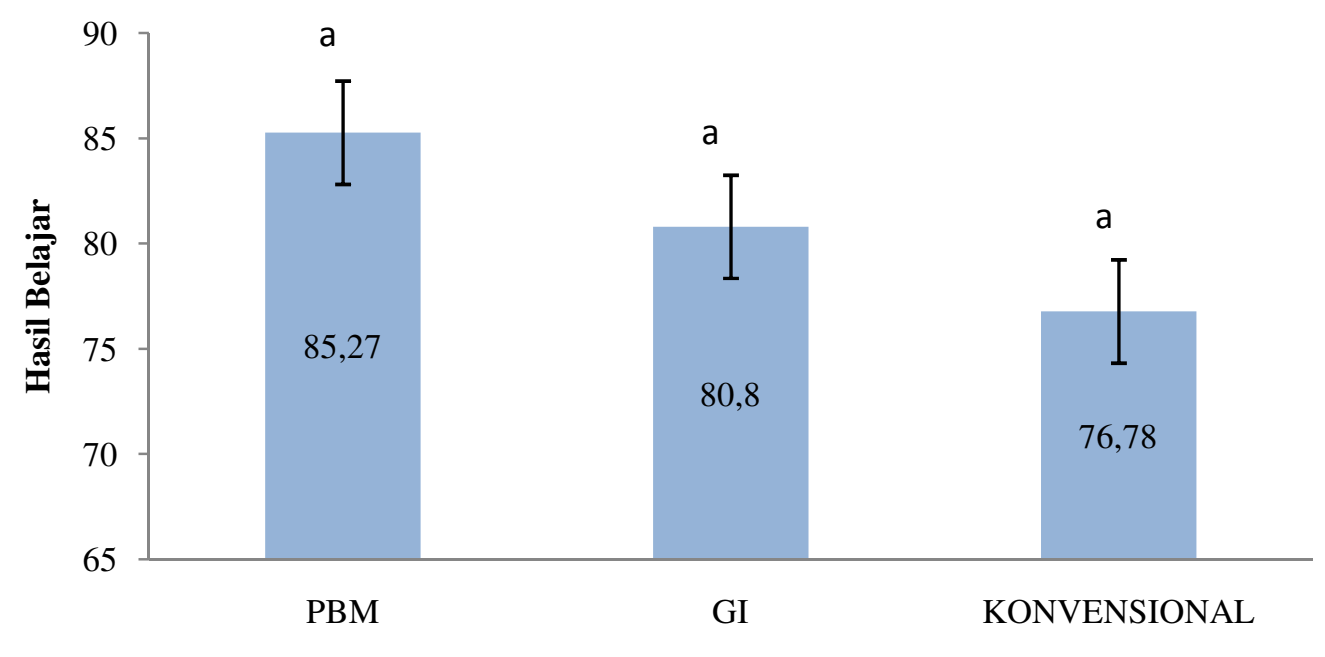

Model Pembelajaran

Gambar 1. Grafik nilai rata-rata hasil belajar siswa yang dibelajarkan dengan model pembelajaran berbasis masalah $(\mathrm{PBM})$, group investigation $(\mathrm{GI})$, dan konvensional $(\mathrm{F}=14,183 ; \mathrm{P}=0,000)$.

Pengaruh strategi pembelajaran terhadap kemampuan berpikir kreatif Hasil analisis kovarian (Anacova) menunjukkan bahwa model pembelajaran berpengaruh terhadap kemampuan berpikir kreatif siswa $(\mathrm{F}=12,030, \mathrm{P}=0,00)$. Selanjutnya uji Tukey menunjukkan bahwa hasil kemampuan berpikir kreatif siswa yang dibelajarkan dengan model PBM tidak berbeda secara signifikan dengan model GI, akan tetapi nilai rata-rata kemampuan berpikir kreatif siswa kelas $\mathrm{PBM} \quad(82,77 \pm 5,30)$ lebih tinggi dibandingkan dengan siswa kelas GI $(80,07 \pm 4,29)$. Sementara itu siswa yang dibelajarkan secara konvensional lebih rendah hasil kemampuan berpikir kreatifnya dibandingkan PBM dan GI yaitu dengan rata-rata 77,00 \pm 4,06 (Gambar 2). 


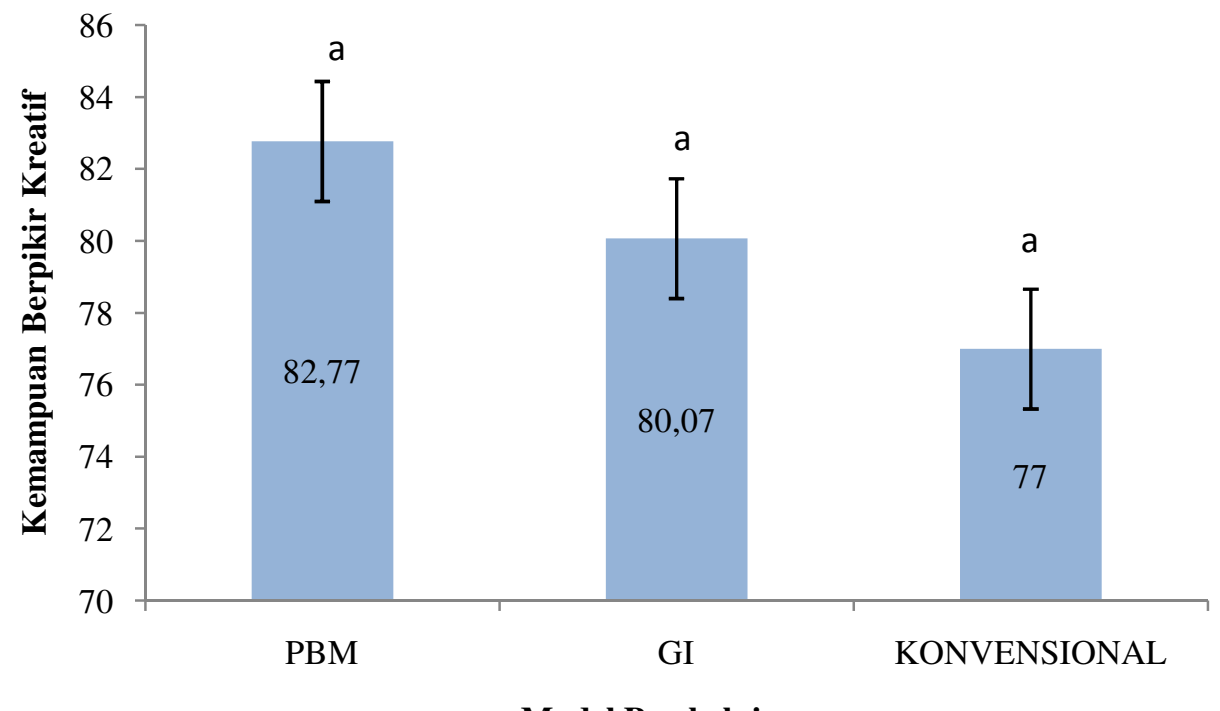

Model Pembelajaran

Gambar 2. Grafik nilai rata-rata kemampuan berpikir kreatif siswa yang dibelajarkan dengan model Pembelajaran Berbasis Masalah (PBM), Group Investigation (GI), dan Konvensional (F = 12,030; P = $0,000)$.

\section{Pembahasan \\ Pengaruh model pembelajaran terhadap hasil belajar siswa}

Pemberian model pembelajaran merupakan suatu hal yang harus menjadi perhatian pendidik, karena dalam proses belajar diarahkan untuk mencapai hasil. Hasil belajar menunjuk pada suatu perolehan akibat dilakukannya suatu aktivitas atau proses yang mengakibatkan perubahnya input secara fungsional. Dengan demikian memilih model pembelajaran yang tepat dapat mendorong tercapainya tujuan pembelajaran yang diinginkan.

Tingginya hasil belajar siswa dengan menggunakan model PBM dikarenakan dalam proses belajarnya, model PBM mengorientasikan "masalah" pada awal pembelajaran, selanjutnya pengetahuan baik berupa konsep maupun fakta yang berkaitan dengan masalah akan didapatkan oleh siswa melalui proses pembelajaran sehingga siswa memiliki kesempatan untuk mengingat pengetahuan jangka panjang yang berdampak pada hasil belajarnya. Hal ini sesuai dengan pendapat Awang dan Ishak (2008) bahwa pembelajaran berbasis masalah memberikan kesempatan kepada siswa untuk memahami teori dan konten pengetahuan secara mendalam.
Meningkatnya hasil belajar dengan menggunakan model PBM juga dikarenakan proses pembelajaran dengan menggunakan model tersebut, dimana siswa memiliki kesempatan untuk terlibat dalam proses belajarnya. Siswa diberikan lembar diskusi yang berisikan permasalahan kontekstual yang berhubungan dengan materi sistem pencernaan makanan. Siswa dituntut untuk memecahkan permasalahan secara aktif baik mandiri maupun berdiskusi dengan anggota kelompoknya. Adanya interaksi tersebut juga memungkinkan siswa saling bertukar pendapat dan informasi sehingga pengetahuan yang diperolehnya akan lebih bermakna. Hal ini sesuai dengan penelitian Utomo et al (2014) bahwa model pembelajaran berbasis masalah berpengaruh terhadap pemahaman konsep siswa kelas VIII SMPN 1 Sumbermalang pada pokok bahasan Sistem Gerak Manusia, dengan nilai soignifikansi sebesar $0,000(<0,005)$. Selanjutnya Steinbach dalam Mauke, et al (2013) menyatakan bahwa dalam PBM, aktivitas pemecahan masalah diawali dengan konfrontasi dan berakhir apabila sebuah jawaban telah diperoleh sesuai dengan kondisi masalah. Pembelajaran berbasis masalah menjadi sangat penting, karena dalam belajar, peserta didik cepat lupa jika hanya dijelaskan secara lisan, 
mereka ingat jika diberikan contoh, dan memahami jika diberikan kesempatan mencoba memecahkan masalah.

\section{Pengaruh model pembelajaran terhadap kemampuan berpikir kreatif siswa}

Dari hasil analisis data, skor rata-rata kelas yang dibelajarkan dengan model PBM lebih tinggi dibandingkan dengan GI, akan tetapi secara statistiik Uji Tukey keduanya tidak berbeda secara signifikan. Hal ini didukung oleh hasil penelitian Arnyana (2006) mengenai "Pengaruh Penerapan Strategi Pembelajaran Inovatif Pada Pelajaran Biologi Terhadap Kemampuan Berpikir Kreatif Siswa SMA" menunjukkan bahwa kelompok siswa yang belajar dengan strategi-strategi pembelajaran inovatif, yaitu strategi Kooperatif GI, PBL, dan Inkuiri menunjukkan kemampuan berpikir kreatif berada pada katagori baik.

Tidak berbedanya kemampan berpikir kreatif siswa pada kelas yang dibelajarkan dengan model PBM dan GI dikarenakan proses pembelajaran yang berlangsung di kedua kelas hampir setara, yaitu pembelajaran dengan paham konstruktivisme (Isjoni, 2009; Tan, 2009). Paham ini membiasakan siswa untuk menemukan pengetahuannya sendiri sehingga proses pembelajaran yang terjadi di kelas menuntun siswa untuk terbiasa bergelut dengan ide-ide dan berpikir secara kreatif.

Pembelajaran secara konstruktivis juga dikategorikan sebagai pembelajaran aktif, hal ini dikarenakan siswa memperoleh pengetahuan karena keterlibatannya secara langsung dalam proses pembelajaran. Dalam hal ini siswa aktif bertanya, aktif menanggapi permasalahan yang ada, aktif menjawab dan memberikan gagasan baik dikelompoknya maupun ketika presentasi di depan kelas.

Sebagai contoh dari hasil penelitian yaitu pada saat proses pembelajaran dengan indikator menjelaskan penyakit yang berhubungan dengan sistem pencernaan makanan pada manusia, maka dengan menggunakan model PBM dan GI mampu mendorong munculnya gagasan/ide siswa mengenai penggunaan tanaman tradisional sebagai alternatif untuk mengobati sakit yang berhubungan dengan sistem pencernaan selain dari yang dijelaskan oleh guru dan yang disebutkan dalam buku. Hal ini dikarenakan siswa berdiskusi di dalam proses pembelajarannya sehingga terjadi pertukaran informasi dan memunculkan solusi-solusi lain yang diketahui dalam mencegah penyakit yang berhubungan dengan sistem pencernaan makanan. Proses pembelajaran aktif yang dilalui siswa inilah yang dapat menumbuhkan kreativitas mereka, karena pada dasarnya kreativitas juga dapat dihasilkan dari kondisi pribadi dan lingkungan (press) individu ke perilaku kreatif (Munandar, 2012).

Pada Pembelajaran berbasis masalah dan group investigation, peran guru hanya sebagai fasilitator dimana nantinya yang akan mengarahkan siswa dalam mengambil keputusan. Sedangkan siswa akan bertindak sebagai objek utama dalam pembelajaran. Siswa akan berdiskusi untuk mendapatkan pengetahuan sesuai dengan materi yang diajarkan. Melalui diskusi siswa akan lebih kreatif untuk mengungkapkan pendapat, menerima pendapat, serta kreatif dalam memberikan pertimbangan dan penilaian. Sedangkan pembelajaran konvensional membiasakan siswa untuk menerima pengetahuan dari guru dan sebatas apa yang ada pada buku. Oleh karena pembelajarannya hanya satu arah, maka siswa cenderung malu untuk mengungkapkan pendapat yang berujung pada terhambatnya kreativitas mereka.

\section{SIMPULAN}

Berdasarkan hasil penelitian dan pembahasan disimpulkan bahwa siswa yang dibelajarkan dengan model pembelajaran berbasis masalah (PBM) memiliki hasil belajar dan kemampuan berpikir kreatif yang lebih tinggi dibandingkan dengan siswa yang dibelajarkan dengan model group investigation (GI) dan konvensional.

\section{DAFTAR PUSTAKA}

Allchin, D. 2013. Problem- and Case-Based Learning in Science: An Introduction to Distinctions, Values, and Outcomes. $C B E$ Life Science Education. 12 (3): 364-372. 
Arnyana, I. B. P. 2006. Pengaruh Penerapan Strategi Pembelajaran Inovatif Pada Pelajaran Biologi Terhadap Kemampuan Berpikir Kreatif Siswa SMA. http://isjd.pdii.lipi.go.id/ admin/jurnal/39306496515.pdf, (online). diakses tanggal 12 Desember 2015.

Awang, H., dan Ishak, R. 2008. Creative Thinking Skill Approach Through ProblemBased Learning: Pedagogy and Practice in the Engineering Classroom. International Journal of Social, Behavioral, Educational, Economic and Management Engineering. 2 (4): 334-339.

BSNP. 2006. Standar Isi untuk Satuan Pendidikan Dasar dan Menengah. Jakarta: Depdiknas.

Isjoni. 2009. Pembelajaran Kooperatif (Meningkatkan Kecerdasan Komunikasi Antar Peserta Didik). Yogyakarta: Pustaka Pelajar.

Mauke, M., I. W. Sadia., I. W. Suastra. 2013. Pengaruh Model Contextual Teaching and Learning Terhadap Pemahaman Konsep dan Kemampuan Pemecahan Masalah dalam Pembelajaran IPA-Fisika di MTs Negeri Negara. Jurnal Program Pascasarjana Universitas Ganesha. Vol 3: 1-12.

Munandar, U. 2012. Pengembangan Kreativitas anak berbakat. Jakarta: Rineka Cipta.

Ristanto, R. H. 2010. Pembelajaran Berbasis Inkuiri Terbimbing Dengan Multimedia Dan Lingkungan Riil Ditinjau Dari Motivasi Berprestasi Dan Kemampuan Awal. Tesis. Program Pascasarjana Universitas Sebelas Maret, Surakarta.

Runco, M. A. 2004. Creativity. Annu. Rev. Psychol. 55: 657-687.

Sungur, S., Ceren, T., Omer, G. 2006. Improving achievement through problembased learning. Educational Research. 40 (4): 155-160.

Tan, O. S. 2009. Problem-Based Learning and Creativity. Canada: Nelson Education.

Utomo, T., Dwi, W., Slamet, H. 2014. Pengaruh Model Pembelajaran Berbasis Masalah (Problem Based Learning) Terhadap Pemahaman Konsep dan Kemampuan Berpikir Kreatif Siswa (Siswa Kelas VIII Semester Gasal SMPN 1 Sumbermalang Kabupaten Situbondo Tahun Ajaran 2012/2013). Jurnal Edukasi Unej. I (1): 5-9. 